aliado a um forte e determinado respaldo político de outros escalões do governo. Felizmente, essa seqüência interminável de negociações teve, fundamentalmente, um apoio coerente do governo. Finalmente conseguimos fechar um contrato de transferência de tecnologia no valor de 3 milhões de dólares, cobrindo exatamente o que pretendíamos e com algumas vantagens. Por exemplo, não havia restrições para repassarmos os conhecimentos a uma empresa fabricante genuinamente nacional. Essa era uma exigência que não abríamos mão, porque, em última análise, a nossa atividade não seria de fabricar, nós estávamos apenas interessados em trazer esse processo porque esse insumo era importante no desenvolvimento e na realização de alguns produtos e a conseqüência natural, tendo em vista o mercado interno de utilização desses insumos, seria passar isso para um fabricante nacional.

Outra coisa que conseguimos, foi o treinamento e a capacitação do nosso pessoal no exterior, em todas as etapas do desenvolvimento do processo de obtenção desse insumo inclusive com o acesso ao know-why que era o que nos interessava. Nós queríamos mudar algumas coisas em função de outros desdobramentos, de outras aplicações e obtivemos também a assistência técnica do fornecedor na instalação e operacionalização de nossa planta-piloto. Inclusive, na medida em que estivéssemos com essa planta em fase de instalação queríamos realizar algumas corridas, digamos assim, de produção desses insumos, nas facilidades existentes na empresa cedente da tecnologia no exterior, queríamos garantias desse aspecto sem custos adicionais.

Outra coisa importante, também conseguida, foi o cronograma de pagamento, escalonado em função do cumprimento sucessivo das diversas etapas do processo. Enfim, tínhamos que escutar os pontos de verificação, que também exigimos; então cada pagamento ficava condicionado a nossa aceitação técnica.

Finalmente, na questão pertinente: nessa linha de atuação como país emergente, determinado e consciente de suas necessidades, não estaremos violando alguma regra intangível do clube dos detentores de tecnologia? Outras experiências serão bem-sucedidas ou terá sido um puro golpe de sorte da nossa parte? Na medida em que adquirirmos competência, as portas não estarão se fechando para determinadas pretensões nossas?

\title{
Tecnologia como participação de capital
}

Samia Rashed, doutora em direito internacional privado (Universidade do Cairo) e consultoralegal em direito internacional.
Samia Rashed

Ihes-ão que precisam de fazer um contrato de transferência de patente, visto que aquela não é reconhecida como participação em espécie. Noutros países, contudo, entre eles o Egito, a tecnologia é aceita e até bem-vinda como participação em espécie, em qualquer companhia. Aceitamo-la, porque nesse caso não precisamos de pagar royalty, não precisamos de despender dinheiro: pelo contrário, obtemo-lo facilmente e com isso promovemos a economia do nosso país. O grande problema está em como avaliar essa tecnologia. Em países como o Egito, por exemplo, a tecnologia é patenteada e como tal pode ser aceita na economia como uma participação em espécie.

Recusamos a participação em espécie de tecnologia que não esteja patenteada, porque achamos 
que o valor dela não é assim tão elevado. Também gostamos de avaliá-la, e isso é importante quando usamos esse método de importar tecnologia. Essa avaliação deverá ser orientada ou ficar sob o controle estrito do governo, de modo a não se destruir a economia do país. É isto que eu, de um modo geral, quero significar com tecnologia como participação em espécie e não um método de comprar ou vender. Mas eu quero referir-me também um pouco a outro assunto: o do contrato de transferência de tecnologia. Há dois pontos importantes, que deverão, sobretudo, ser tomados em consideração, ou seja, o problema da inovação na melhoria da tecnologia. Essa previsão terá de ser olhada com bastante cuidado, visto que muitas vezes na transferência da tecnologia não se inclui qualquer inovação. De repente, verificamos que a tecnologia, que compramos, que pagamos e pela qual estamos ainda pagando royalties, não está mais atualizada, havendo nela muitas inovações. Então essa providência tem de ser tomada com muito cuidado, pois será bom consegui-la sem aumento de encargos, ou, não sendo isso possível, há que estabelecer limites ou critérios quanto à aquisição dessa nova tecnologia ou esse novo progresso e acrecentá-la à tecnologia já adquirida e que estamos pagando. As inovações sempre implicam pesquisa e, assim, é de perguntar quem vai custear essa pesquisa. Esse é um aspecto que precisa ser bemelaborado. Um outro ponto ainda, uma vez que se importou e está utilizando tecnologia, é o das meIhorias por nós introduzidas.

Se o país de origem é titular dessa tecnologia, a nova melhoria, livre ou não de encargos, deverá figurar no acordo de transferência de tecnologia, o qual portanto e uma vez mais, tem de ser olhado com todo o cuidado. Um outro ponto ainda é o território abrangido por esse acordo de transferência.

Normalmente, as companhias pretendem limitar esse território ao do país que está importando tecnologia. Eu acho, no entanto, que é preciso ver se, num esquema mais vasto, elas não vão importar o produto final para países vizinhos e providenciar a respeito no acordo de licenciamento. O último ponto está talvez relacionado com aquilo que o nosso embaixador falou acerca do compromisso político do governo. Ouvi dizer que o benefício de ter negociações compactas em relação à tecnologia, acordos de serviços técnico e de suprimento é realmente um ponto de muito interesse quando procuramos ter uma política em que a tecnologia não seja demasiada elevada, pois assim poderemos avaliá-la meIhor e extrair dela mais benéficos efeitos, desde que o acordo se faça mais na base de serviço técnico, em que se obterá mais dinheiro, do que sob o rótulo de transferência de tecnologia ou com referência a ela. É um acordo separado e dele se poderá tirar maior lucro sem realmente comprometer ou atingir a opinião política do país. Se eu fosse o país importador da tecnologia, olharia com muitas dúvidas esse tipo de acordo compacto, onde o contrato de serviço técnico acresce e é talvez o suprimento de mercadorias, pois tudo isso pode ser feito em detrimento ou talvez como uma forma velada de aumentar valor à tecnologia. 